\title{
NARRATIVAS AUTOBIOGRÁFICAS SOBRE O LUGAR: SIGNIFICAÇÃO E CONSTRUÇÃO DE SABERES, VIVÊNCIAS E AFETIVIDADES DE ALUNOS DA EDUCAÇÃO BÁSICA DE FEIRA DE SANTANA - BA.
}

\author{
JAQUELINE DE JESUS DE LEMOS
}

1.Bolsista Probic-Uefs, Graduanda de Licenciatura em Geografia, Universidade Estadual de Feira de Santana, email:

jake-1lyne@,hotmail.com

\section{CLÉA CARDOSO DA ROCHA ${ }^{2}$}

2. Orientadora, Departamento de Educação, Universidade Estadual de Feira de Santana, email: cleabase@yahoo.com.br

\section{PALAVRAS CHAVES: NARRATIVAS AUTOBIOGRAFICAS; LUGAR; ENSINO DE GEOGRAFIA.}

\section{INTRODUÇÃO}

Esta pesquisa teve por finalidade em compreender como o conceito de lugar é formado pelos os alunos do $6^{\circ}$ ano do ensino fundamental II da educação básica das escolas públicas de Feira de Santana, a partir da utilização das narrativas autobiográficas como um instrumento pedagógico para reconhecer como esses sujeitos desenvolvem as suas relações sócio-espaciais e se constroem o conceito de lugar a partir das suas vivências.As narrativas autobiográficas são entendidas como o método que procura entender como os sujeitos se compreende, individual e socioculturalmente. Deste modo, atividades de intervenção foram desenvolvidas em uma escola publica de Feira de Santana que atende do $6^{\circ}$ ao $9^{\circ}$ ano do ensino fundamental II, com a faixa etária de 10 a 15 anos de idade, e se destaca por realizar a educação inclusiva.

Foram realizadas duas intervenções em turmas do $6^{\circ}$ ano em períodos diferentes, pois os resultados alcançados na primeira intervenção não foram suficientes para alcançar os objetivos da pesquisa.Sendo assim, as duas intervenções foram desenvolvidas junto o plano de trabalho, intitulado "Olhares fotográficos, mediações e expressões do Lugar: experimentações com alunos do ensino básico de Feira de Santana- BA.”. Nas duas turmas observadas aplicou-se um questionário sócio cultural e foram produziram narrativas autobiográficas.

A primeira intervenção aconteceu entre os meses de novembro e dezembro de 2016, a turma é composta por 20 alunos com a faixa de 11 a 15 anos, sendo que, dois alunos são portadores de necessidades especiais: um aluno com síndrome de Down e uma aluna com paralisia cerebral, por esse motivo, as atividades para eles tiveram que ser diferenciadas, porém, apenas o aluno com Down conseguiu realizar essa atividade e no lugar do texto escrito ele desenhou o que foi proposto com o auxílio da mediadora. Vale destacar que, essa turma por estar finalizando o terceiro ciclo já tinha estudado no ciclo anterior a categoria de análise geográfica lugar.

Na segunda etapa, foi levada uma apresentação no qual mostrava conceitos sobre lugar na visão dos autores: Carlos (1995) e de Tuan (1983), e algumas fotografias sobre diversos lugares e também de Feira de Santana. A partir desta discussão foi solicitada para os alunos a elaboração de um texto chamado de "meu lugar", no qual, eles contariam o que seria o seu lugar e quais as suas relações com esses lugares narrados nos textos, vale lembrar que, esses textos foram totalmente livres e são chamados de autobiográficos por dar conta das suas vivências. Já, na última etapa foi destinada à apresentação do painel com os textos e também das fotografias da intervenção da outra bolsista, nesse momento, os alunos tiveram a chance 
de falar o que realmente estavam representados nos textos e nas fotos, e aproveitaram a ocasião para fazer uma reflexão do que tinha sido trabalhado na intervenção.

A segunda intervenção ocorreu nosmeses de maio e junho de 2017, a turma possui 17 alunos, com a faixa etária entre 11 a 14 anos e nesta turma também encontrou-se uma aluna portadora de necessidades especiais (com síndrome de Down e um pequeno grau de autismo), a mesma participou da atividade proposta, ao invés de escrever o texto ela também desenhou o que representaria o seu lugar, a exemplo do aluno da primeira intervenção. Essa turma não havia estudado o conceito de lugar, pois ainda estava no primeiro ciclo letivo. Foram realizadas as mesmas etapas com a primeira turma, diferenciando-se pela apresentação de um vídeo de um morador de Feira de Santana que conta a sua relação com a cidade e com o bairro em quem mora.

\section{MATERIAIS E MÉTODOS}

Foram utilizados os materiais e métodos presentes no plano de trabalho "Narrativas autobiográficas sobre o lugar: significação e construção de saberes, vivências e afetividades de alunos da educação básica de Feira de Santana - BA. ', baseada em pressuposto da pesquisa-ação, do método etnográfico e também utilizando a metodologia da análise do conteúdo, a partir das orientações de Moraes (1999) para interpretar as narrativas autobiográficas. Portanto as atividades desenvolvidas foram: Levantamento bibliográfico sobre as temáticas abordadas; discussão teórica no grupo de pesquisa; visita a escola campo; planejamento e desenvolvimento das intervenções; identificação do conceito de lugar presentes nas narrativas; sistematização e análise dos dados; elaboração do relatório e construção de artigos para eventos.

\section{RESULTADOS}

Na primeira turma mesmo com os alunos já tendo estudado o conceito de lugar no ciclo letivo anterior, percebemos que eles ainda não conseguiam ter uma compreensão do que realmente seria esse lugar, isso é notável, principalmente nas respostas dadas nos questionários, pois todos estavam apenas associando a um espaço qualquer, ao lugar de lazer e divertimento, a uma cidade qualquer e a moradia, percebendo-se que as respostas foram dadas sem uma real compreensão do conceito.

Ao partirmos para a conceituação do lugar e a produção das narrativas, aqueles mesmos alunos já mudaram os seus textos e passaram a acrescentar outros lugares que eles agora conseguem compreender como também o seu lugar. Portanto, nas narrativas eles continuaram apresentando a casa como o seu lugar, porém foram acrescentadas a cidade e a escola só que agora com o reconhecimento e o sentimento de pertencimento com esses lugares descritos nas narrativas.

Já na segunda intervenção, os alunos encontravam-se no primeiro ciclo e não tinham discutido o conceito. Porém, as suas respostas sobre lugar no questionário foram semelhantes com as respostas da primeira turma, diferenciando-se pela categoria bairro considerado como o seu lugar, ou seja, esse aluno em especial já identificava sua relação de afetividade e pertencimento antes mesmo de saber o conceito de lugar.

Após a apresentação do conceito de lugar (com apresentação de um vídeo de um morador de Feira de Santana que conta a sua relação com a cidade e também com o seu bairro) e, consequentemente, a produção das narrativas, esses alunos passaram apresentar nos seus textos: a praça próxima de casa como um lugar, pois é destinado ao lazer e divertimento com os amigos; o campo (zona rural), pois aqui é o seu lugar de moradia e sente-se bem e seguro diferente da cidade; e o bairro que a maioria dos alunos passou a considerar como também o 
seu lugar; e também a cidade, pois alguns alunos em suas narrativas compreenderam que Feira de Santana também é o seu lugar por ser, além do seu local de nascimento, o lugar das suas relações afetivas (família, amigos, colegas e etc.), que vivem nesta cidade fazendo com que, esses alunos passassem a reconhecer a cidade como o seu lugar no decorrer das narrativas.

\section{CONCLUSÃO}

Estudar o conceito de lugar nas aulas da disciplina de geografia é extremamente necessário para os sujeitos, em especial, para os alunos do $6^{\circ}$ ano do ensino fundamental II, pois os mesmos irão descobrir e compreender as suas relações e sentimentos de pertencimento, afetividade e de identidade nos lugares onde estão inseridos.

Destaca-se assim, a utilização das narrativas autobiográficas como o instrumento pedagógico nesta pesquisa de iniciação cientifica, auxiliou a compreender como esses alunos construíram e pensaram o conceito de lugar identificados nos seus textos. Pois, a partir deste instrumento ficaram visíveis as relações e os sentimentos dos mesmos no decorrer de cada narrativa produzida. Através das narrativas eles identificaram relações e sentimentos que anteriormente não foram expressos, nem através dos questionários ou das suas falas.

Os resultados alcançados nas duas intervenções com as narrativas foram semelhantes. Observando-se, no entanto, que na segunda os resultados foram mais ricos, expressos em categorias novas apresentadas, o que atribuímos à apresentação do vídeo com o morador que expressa sua relação com a cidade. Conclui-se que através da produção das narrativas os alunos deixaram de pensar no lugar como algo distante e externo a eles e passaram a compreendê-lo como próximo e presentes nas suas vivências, onde traçam relações, experiências.

\section{REFERÊNCIAS}

CARLOS, Ana Fani Alessandri. O lugar no/do mundo. Encontro Nacional de Pós Graduação em Geografia: Aracajú, 1995.

MORAES, Roque. Análise de conteúdo. Revista Educação, Porto Alegre, v. 22, n. 37, p. 7-32, 1999.

TUAN, YI-FU. Espaço \& lugar. São Paulo: Difel, 1983. 